\title{
HAK INGKAR NOTARIS SEBAGAI SAKSI DALAM PERADILAN PIDANA
}

\author{
Arum Dewi Azizah Salsabila, Suhariningsih, Ismail Navianto \\ Program Studi Magister Kenotariatan Fakultas Hukum Universitas Brawijaya \\ JL. MT. Haryono Nomor 169 Malang \\ email: adasalsabila@gmail.com
}

\begin{abstract}
: the purpose of this study was to find out why the notary right of refusal can not be used in criminal justice and what are the legal implications of a notary if a notary becomes a witness in a criminal court. This research uses normative juridical research method with the approach of legislation, conceptual, historical, case. The notarization rights can not be used in criminal justice because the criminal proofing system in Indonesia, the position of witness testimony in the search for truth materill, and the principle of examination of judge who directly and orally. As well as the legal implications arising from the right to a notary if the notary has been approved by the Notary Board of Honor (MKN) to appear as a witness in a criminal court that the notary's right is void.
\end{abstract}

Keywords: The right of notary's refusal, witness, criminal justice

\begin{abstract}
Abstrak: tujuan dari penulisan ini adalah mengetahui mengapa hak ingkar notaris tidak dapat digunakan dalam peradilan pidana dan apa implikasi hukum terhadap hak ingkar notaris jika notaris menjadi saksi dalam peradilan pidana. Kajian ini menggunakan metode yuridis normatif dengan pendekatan perundang-undangan, konseptual, historis, dan kasus. Hak ingkar notaris tidak dapat digunakan dalam peradilan pidana karena sistem pembuktian pidana di indonesia, kedudukan keterangan saksi dalam pencarian kebenaran materiil, dan asas pemeriksaan hakim yang langsung dan lisan serta implikasi hukum yang timbul terhadap hak ingkar notaris apabila notaris telah diizinkan oleh Majelis Kehormatan Notaris (MKN) untuk hadir sebagai saksi dalam peradilan pidana yaitu bahwa hak ingkar notaris tersebut gugur.
\end{abstract}

Kata Kunci: Hak ingkar notaris, saksi, peradilan pidana

Persetujuan Majelis Kehormatan Notaris (MKN) kunci pembuka kewajiban hak ingkar notaris. Hak ingkar adalah adalah hak untuk menolak untuk memberikan kesaksian atau hak untuk minta undur dari kesaksian (verchoningrecht). Di dalam hak ingkar notaris tersebut terkandung kewajiban untuk tidak bicara (verschoningsplicht) sehingga notaris tidak hanya berhak untuk tidak bicara (verchoningrecht), akan tetapi mempunyai kewajiban untuk tidak bicara (verschoningrecht) (Tobbing, 1992:122). Namun hak ingkar notaris tidak dapat digunakan dalam peradilan pidana.

Putusan Mahkamah Agung Republik Indonesia nomor 685/ Pid.B/2016/PN Malang terkait kasus pemalsuan, bahwa pemilik sah tanah yang terletak di desa Pesanggrahan kecamatan Batu kota Batu yaitu Juliawati, Natalia Lindiana,
Roosdiana, Hari Susanto, Mingawati, Harijanto, Soehandojo, dan Handika Susilo sedangkan pemilik sah villa kipas desa Sidomulyo kecamatan Batu kota Batu yaitu Elly Machdalena. Terdakwa Drs. Tjonet Soeharyanto telah terbukti secara sah dan meyakinkan bersalah melakukan tindak pidana dengan meminta Rr. Intan Febriana menempatkan keterangan palsu untuk membuat untuk membuat akta autentik berupa perjanjian pengikatan jual beli atas obyek tanah yang terletak di desa Pesanggrahan kecamatan Batu kota Batu dan villa kipas desa Sidomulyo kecamatan Batu kota Batu dihadapan notaris Roy Pudyo Hermawan, $\mathrm{SH}$, Sehingga notaris tersebut dipanggil untuk menjadi saksi dalam persidangan peradilan pidana terkait akta pengikatan jual beli yang telah notaris buat sesuai dengan permintaan terdakwa. 
Putusan Mahkamah Agung Republik Indonesia nomor 603/Pid.B/2017/PN Denpasar terkait kasus pemalsuan surat pelunasan tanah atau kwitansi pembayaran tanah. Terdakwa R. Gerard Aria Warmadewa membuat kwitansi tersebut dengan tujuan untuk ditunjukkan kepada notaris I Wayan Sugita, SH sebagai bukti seolah-olah terdakwa telah melunasi pembayaran tanah kepada pemilik tanah yaitu I Slamet Santoso. Hal ini dilakukan terdakwa agar notaris bersedia membuatkan akta autentik berupa perjanjian pengikatan jual beli yang diminta oleh terdakwa. Sehingga notaris tersebut dipanggil untuk menjadi saksi dalam persidangan peradilan pidana terkait akta pengikatan jual beli yang telah notaris buat sesuai dengan permintaan terdakwa.

Indonesia menganut sistem eropa kontinental, dalam sistem eropa kontinental penentuan bersalahnya seseorang terdakwa digantungkan pada keyakinan hakim yang muncul dari minimal dua alat bukti yang sah, Keterangan saksi menempati posisi teratas dibandingkan alat bukti yang lainnya dari Pasal 184 - 185 kitab Undangundang hukum acara pidana selanjutnya disebut KUHAP yang menerapkan keterangan saksi pada urutan pertama hal ini juga dikarenakan keterangan saksi merupakan alat bukti yang pertama kalinya diperiksa dalam tahap pembuktian didalam persidangan dan menjadi saksi adalah kewajiban hal ini termuat dalam Pasal 224 ayat (1) kitab Undang-Undang Hukum Pidana selanjutnya disebut KUHP, sehingga bila orang tersebut tidak hadir atau memenuhi kewajiban tersebut, maka aparat penegak hukum dapat mendakwanya melakukan tindak pidana.

Ketentuan pada Undang- undang jabatan notaris perubahan Pasal 16 ayat (1) huruf f yang menyatakan bahwa notaris wajib menyimpan semua rahasia terhadap akta yang menjadi tanggungjawabnya serta rahasia atas semua keterangan yang masuk kepadanya terkait akta yang menjadi tanggungjawabnya tersebut yang berkaitan sumpah atau janji jabatan, terkecuali Undang- undang mengatur lain terjadi kekaburan norma dengan pengaturan mengenai saksi yang termuat dalam Pasal 224 ayat (1) KUHP, bahwa menjadi saksi adalah kewajiban. Namun dalam Pasal 170 ayat (1) KUHAP menjelaskan mereka yang karena pekerjaan, harkat martabat, atau jabatannya diwajibkan menyimpan rahasia, dapat minta dibebaskan dari kewajiban untuk memberi keterangan sebagai saksi, yaitu tentang hal yang dipercayai kepada mereka. Akan tetapi dalam Putusan Mahkamah Agung Republik Indonesia nomor 685/ Pid.B/2016/PN Malang dan Putusan Mahkamah Agung Republik Indonesia nomor 603/ Pid.B/2017/PN Denpasar dengan memperjelas bahwa notaris tetap dihadirkan sebagai saksi dalam peradilan pidana. Sehingga muncul problematika teoritis yaitu adanya ketidakpastian hukum terkait penggunaan hak ingkar notaris karena dalam putusan Putusan Mahkamah Agung Republik Indonesia nomor 685/ Pid.B/2016/PN Malang dan Putusan Mahkamah Agung Republik Indonesia nomor 603/Pid.B/2017/PN Denpasar notaris tetap hadir sebagai saksi dalam peradilan pidana.

Berdasarkan hal tersebut diatas, maka penulis mengangkat judul "Hak Ingkar Notaris Sebagai Saksi Dalam Peradilan Pidana". Tulisan ini berusaha untuk menganalisis keberadaan hak ingkar notaris sebagai saksi yang tidak dapat digunakan dalam peradilan pidana dan implikasi hukum terhadap hak ingkar notaris apabila notaris telah diizinkan oleh majelis kehormatan notaris untuk hadir sebagai saksi dalam peradilan pidana.

\section{METODE}

Kajian tentang hak ingkar notaris sebagai saksi dalam kasus pidana ini menggunakan yuridis normatif dengan pendekatan perundang-undangan, konseptual, kasus, dan historis. Bahan hukum primer yang digunakan adalah Kitab UndangUndang Hukum Pidana dan Kitab UndangUndang Hukum Acara Pidana.

\section{HASIL DAN PEMBAHASAN}

\section{Argumentasi Hak Ingkar Notaris sebagai Saksi dalam Peradilan Pidana Tidak dapat Digunakan}

Peraturan hak ingkar notaris yang belum terbentuk dalam peraturan yang mengatur tentang jabatan notaris mengakibatkan ketidakpastian hukum terhadap notaris dalam menjalankan jabatannya. Ketika notaris dipanggil sebagai saksi dalam peradilan pidana yang terlibat dalam perkara hukum antara lain disebabkan karena adanya kesalahan pada akta yang dibuatnya, baik karena kesalahan notaris itu sendiri maupun kesalahan para pihak, atau salah satu pihak yang tidak memberikan keterangan atau dokumen yang 
sebenarnya (tidak adanya itikad baik dari para pihak atau salah satu pihak), atau telah ada kesepakatan antara notaris dengan salah satu pihak yang menimbulkan kerugian pada pihak lain. Berikut adalah kasus yang terjadi dalam ranah pidana terkait akta autentik yang dibuat oleh notaris, dengan mengacu pada putusan Mahkamah Agung Republik Indonesia.

Putusan Mahkamah Agung Republik Indonesia nomor 685/ Pid.B/2016/PN Malang terkait kasus pemalsuan keterangan, bahwa pemilik sah tanah yang terletak di Desa Pesanggrahan Kecamatan Batu Kota Batu yaitu Juliawati, Natalia Lindiana, Roosdiana, Hari Susanto, Mingawati, Harijanto, Soehandojo, dan Handika Susilo sedangkan pemilik sah villa kipas Desa Sidomulyo Kecamatan Batu Kota Batu yaitu Elly Machdalena. Terdakwa Drs. Tjonet Soeharyanto telah terbukti secara sah dan meyakinkan bersalah melakukan tindak pidana dengan meminta Rr. Intan Febriana menempatkan keterangan palsu untuk membuat akta autentik berupa perjanjian pengikatan jual beli atas obyek tanah yang terletak di Desa Pesanggrahan Kecamatan Batu Kota Batu dan villa kipas Desa Sidomulyo Kecamatan Batu Kota Batu dihadapan notaris Roy Pudyo Hermawan, SH, Sehingga notaris tersebut dipanggil untuk menjadi saksi dalam persidangan peradilan pidana terkait akta pengikatan jual beli yang telah notaris buat sesuai dengan permintaan terdakwa.

Putusan Mahkamah Agung Republik Indonesia nomor 603/Pid.B/2017/PN Denpasar terkait kasus pemalsuan surat pelunasan tanah atau kwitansi pembayaran tanah. Terdakwa R. Gerard Aria Warmadewa membuat kwitansi tersebut dengan tujuan untuk ditunjukkan kepada notaris I Wayan Sugita, SH sebagai bukti seolah-olah terdakwa telah melunasi pembayaran tanah kepada pemilik tanah yaitu I Slamet Santoso. Hal ini dilakukan terdakwa agar notaris bersedia membuatkan akta pengikatan jual beli yang diminta oleh terdakwa. Sehingga notaris tersebut dipanggil untuk menjadi saksi dalam persidangan peradilan pidana terkait akta pengikatan jual beli yang telah notaris buat sesuai dengan permintaan terdakwa.

Notaris mempunyai kewenangan untuk membuat suatu akta autentik mengenai seluruh perbuatan, perjanjian, dan penetapan yang diwajibkan oleh peraturan hukum dan/ atau yang dikehendaki oleh yang berkepentingan untuk di konstantir ke dalam suatu akta autentik. Akta yang dibuat "oleh" maupun "dihadapan" notaris tersebut dapat menjadi alat bukti yang sah manakala akta yang dibuatnya menjadi objek sengketa.

Apabila dianalisis berdasarkan kasus yang telah ada dalam Putusan Mahkamah Agung Republik Indonesia nomor 685/ Pid.B/2016/PN Malang terkait kasus pemalsuan keterangan dan Putusan Mahkamah Agung Republik Indonesia nomor 603/Pid.B/2017/PN Denpasar terkait kasus pemalsuan surat pelunasan tanah atau kwitansi pembayaran tanah bahwa jelas disini kedua notaris tersebut tidak menggunakan hak ingkarnya.

Hak ingkar notaris tidak dapat digunakan dalam peradilan pidana karena beberapa faktor, yaitu:

\section{Sistem Pembuktian Pidana di Indonesia}

Sistem pembuktian pidana di Indonesia adalah sistem pembuktian negatif. Sistem pembuktian negatif (negative wettelijk) ini hampir sama dengan sistem pembuktian conviction in raisonne. Tolak ukur pengambilan keputusan oleh hakim tentang besar atau salahnya terdakwa adalah alat bukti yang ditetapkan oleh undangundang dan keyakinan hakim itu sendiri (Sasangko, 1996:12).

Dalam sistem pembuktian ini ada 2 (dua) syarat (Sasangka, 1996:12) yang harus dipenuhi dalam membuktikan kesalahan terdakwa, yaitu: a. Wettelijk

Terdapat alat bukti yang sah yang telah ditetapkan oleh undang- undang; dan

\section{b. Negatief}

Adanya keyakinan (nurani) hakim yang berdasarkan alat bukti tersebut dimana hakim meyakini kesalahan terdakwa.

Berdasarkan sistem pembuktian pidana terdapat alat bukti yang sah yang telah ditetapkan Undang-undang adalah alat yang ada hubungannya dengan suatu tindak, dimana alat-alat tersebut dapat dipergunakan sebagai bahan pembuktian guna menimbulkan keyakinan kepada hakim atas kebenaran adanya suatu tindak pidana yang telah dilakukan terdakwa.

Alat bukti yang sah menurut Pasal 184 KUHAP adalah keterangan saksi, keterangan ahli, surat, petunjuk, dan keterangan terdakwa. Keterangan saksi adalah suatu alat bukti di dalam perkara pidana yang berupa keterangan dari saksi 
mengenai suatu peristiwa pidana yang ia saksikan, ia lihat sendiri, dan ia alami sendiri dengan menyebutkan alasan dari pengetahuannya seperti halnya yang termuat dalam Pasal 1 butir 27 KUHAP.

Keterangan ahli adalah keterangan yang diberikan oleh seorang yang memiliki keahlian khusus tentang hal yang diperlukan untuk membuat terang tentang suatu perkara pidana guna kepentingan pemeriksaan. Hal tersebut termuat dalam ketentuan Pasal 1 butir 28 KUHAP.

Surat, tentang alat bukti ini diatur dalam Pasal 187 KUHAP sebagai berikut:surat sebagaimana tersebut dalam Pasal 184 ayat (1) c KUHAP dibuat atas sumpah jabatan atau dikuatkan dengan sumpah adalah:

1. Berita acara dan surat lain dalam bentuk resmi yang di buat dihadapannya yang memuat keterangan tentang kejadian atau keadaan yang dialami, dilihat atau yang dialami sendiri disertai dengan alasan yang jelas dan tegas tentang keterangan itu;

2. Surat yang dibuat menurut ketentuan peraturan perundangan atau surat yang dibuat oleh pejabat mengenai hal yang termasuk dalam tatalaksana yang menjadi tanggung jawabnya yang diperuntukkan bagi pembuktian sesuatu hal atau sesuatu keadaan;

3. Surat keterangan dari seseorang ahli yang memuat pendapat berdasarkan keahliannya mengenai sesuatu hal yang atau sesuatu keadaan yang diminta secara resmi daripadanya;

4. Surat lain yang hanya dapatberlaku jika ada hubungannya dengan isi dari alat pembuktian yang lain.

Dalam Pasal 188 KUHAP disebutkan: petunjuk adalah perbuatan, kejadian atau keadaan yang karena persesuaiannya, baik antara yang satu dengan yang lain maupun dengan tindak pidana itu sendiri, menandakan bahwa telah terjadi suatu tindak pidana dan siapa pelakunya petunjuk sebagaimana mestinya dimaksud dalam ayat 1 hanya dapat diperoleh dari keterangan saksi, surat, dan keterangan terdakwa. Penilaian atas kekuatan pembuktian dari suatu petunjuk dalam setiap keadaan tertentu dilakukan oleh hakim dengan arif bijaksana, setelah ia mengadakan pemeriksaan dengan penuh kecermatan dan keseksamaan berdasarkan hati nuraninya.

Keterangan terdakwa diatur dalam Pasal 139 KUHAP. Keterangan terdakwa ialah apa ayang terdakwa nyatakan disisang tentang perbuatan yang ia lakukan, yang ia ketahui sendiri atau alami sendiri. Keterangan terdakwa yang diberikan diluar sidang dapat digunakan untuk membantu menemukan bukti disidang, asalkan keterangan itu didukung oleh suatu alat bukti yang sah sepanjang mengenal hal yang, didakwakan kepadanya. Keterangan terdakwa hanya dapat digunakan terhadap dirinya sendiri. Keterangan terdakwa saja tidak cukup untuk membuktikan bahwa ia bersalah melakukan perbuatan yang didakwakan kepadanya, melainkan harus disertai alat bukti yang lain.

Akta autentik yang merupakan isi kehendak para pihak yang telah dibuat notaris tersebut dalam hukum acara pidana dapat dikategorikan sebagai alat bukti surat dan apabila akta otentik tersebut termasuk dalam alat bukti yang dibutuhkan oleh hakim dalam memutus perkara pidana, maka hakim juga dapat meminta fotokopian dari minuta akta tersebut, hal ini telah diatur didalam Pasal 66 ayat (2) Undang- undang jabatan notaris perubahan.

Akta autentik yang dibuat oleh dan dihadapan notaris tersebut menjadi salah satu alat bukti dari dua alat bukti yang minimal dibutuhkan hakim dalam memutus perkara. Untuk memutus perkara pidana, hakim memerlukan mnimal 2 (dua) alat bukti dan keyakinan untuk memutus suatu perkara, sehingga tidak menutup kemungkinan bahwa keterangan notaris tersebut dapat menjadi salah satu alat bukti yang dibutuhkan hakim untuk memutus perkara pidana.

Bahwa ketika notaris dihadirkan dalam sidang sebagai saksi, yang dibutuhkan aparat penegak hukum adalah menemukan kebenaran dalam perkara pidana dan ini memerlukan notaris sebagai pihak yang meng-konstantir kehendak para pihak dan juga membutuhkan keterangan notaris terkait akta- akta yang telah dibuatnya bagi para pihak.

\section{Kedudukan keterangan saksi dalam pencarian kebenaran materill}

Pasal 183 KUHAP ditegaskan bahwa hakim tidak boleh menjatuhkan pidana kepada seorang kecuali apabila dengan sekurang-kurangnya dua alat bukti yang sah ia memperoleh keyakinan bahwa suatu tindak pidana benar- benar terjadi dan bahwa terdakwalah yang bersalah melakukannya. Dalam pasal ini, yang menganut 
sistem pembuktian menurut undang- undang sampai suatu batas (negatief wettelijk bewijsleer) ditentukan dua syarat untuk menjatuhkan pidana terhadap seseorang, yaitu: (a) adanya sekurang-kurangnya dua alat bukti yang sah, dan (b) adanya keyakinan pada hakim yang diperoleh berdasarkan alat- alat bukti tersebut.

Dalam rumusan Pasal 183 KUHAP tampak pula bahwa alat- alat bukti yang diperlukan adalah sekurang- kurangnya 2 (dua) alat bukti yang sah. Dengan kata lain, alat bukti yang paling minimum adalah 2 (dua) alat bukti yang sah. Pencarian kebenaran materill, yaitu kebenaran yang sesungguhnya, pada dasarnya memerlukan buktibukti yang memadai. Makin banyak bukti yang dapat ditemukan dan dikemukakan di depan sidang pengadilan, di mana bukti- bukti bersesuaian satu dengan yang lain, maka makin besar kemungkinan untuk menemukan kebenaran materill. Tetapi, pembentuk KUHAP dalam Pasal 183 hanya menentukan syarat minimum 2 (dua) alat bukti saja. Ketentuan ini karena pertimbangan logis dan praktis bahwa banyak tindak pidana yang hanya sedikit memiliki alat bukti. Ini karena banyak pelaku tindak pidana yang melakukan perbuatannya dengan sangat berhati-hati agar tidak diketahui orang lain. Dalam keadaan seperti ini, hanya sedikit bukti yang dapat ditemukan. Dengan demikian, sistem pembuktian yang dianut dalam Pasal 183 KUHAP, khususnya ketentuan tentang dua alat bukti yang sah, merupakan ketentuan bersifat kompromi atau jalan tengah. Di satu pihak, kebenaran materill sebenarnya akan makin dapat terjamin kemungkinan tercapainya apabila banyak bukti yang diajukan, tetapi di lain pihak sulit untuk menemukan alat bukti dalam tindak pidana. Sebagai kompromi atau jalan tengah, maka ditentukan syarat minimum berupa 2 (dua) alat bukti yang sah. Berkenaan dengan ketentuan tentang keharusan adanya 2 (dua) alat bukti yang sah ini, dapat dikemukakan bahwa dalam kepustakaan hukum acara pidana banyak kali dikemukakan adanya asas "satu saksi bukan saksi", yang dalam bahasa Latin disebut: unus testis nullus testis. Asas ini mengesankan seakan-akan selalu diperlukan adanya 2 (dua) orang saksi untuk menghindari terjadinya kemungkinan salah tafsir maka dalam KUHAP telah diadakan Pasal 185 ayat (2) dan (3) yang memberikan ketentuan, Pasal 185 ayat (2) Keterangan seorang saksi saja tidak cukup untuk membuktikan bahwa terdakwa bersalah terhadap perbuatan yang didakwakan kepadanya. Pasal 185 ayat (3) Ketentuan sebagaimana dimaksud dalam ayat (2) tidak berlaku apabila disertai dengan suatu alat bukti yang sah lainnya.

Dengan demikian asas unus testis nullus testis hanya mengandung arti bahwa keterangan 1 (satu) orang saksi saja tidak mencukupi jika tidak didukung oleh alat bukti yang sah lainnya. Jadi apabila ada satu orang saksi dan satu alat bukti yang sah lainnya, maka hal tersebut telah memenuhi minimum pembuktian yang dikehendaki oleh Pasal 183 KUHAP. Dalam KUHAP, keterangan saksi merupakan salah satu alat bukti yang sah. Dalam rumusan Pasal 184 ayat (1), keterangan saksi diletakkan dalam urutan pertama. Ini menunjukkan bahwa keterangan saksi memiliki kedudukan yang penting dalam hal pembuktian. Dalam praktek pada banyak kasus tindak pidana, keterangan saksi merupakan alat bukti utama. Dari para saksi tersebut dapat diperoleh keterangan tentang bagaimana jalannya peristiwa yang merupakan tindak pidana. Tetapi, menjadi pertanyaan apakah ada jaminan yang kuat bahwa setiap saksi pasti akan memberikan keterangan yang sebenarnya? Jaminan dari segi yuridis saksi akan memberikan keterangan yang sebenarnya adalah bahwa saksi itu disumpah. Dalam Pasal 160 ayat (3) KUHAP ditentukan bahwa sebelum memberikan keterangan, saksi wajib mengucapkan sumpah atau janji menurut cara agamanya masingmasing, bahwa ia akan memberikan keterangan yang sebenarnya dan tidak lain daripada yang sebenarnya. Dengan diucapkan sumpah atau janji ini maka diharapkan saksi tidak berani memberikan keterangan yang tidak benar, baik karena perasaan/keyakinan keagamaannya ataupun karena adanya ancaman pidana terhadap perbuatan memberikan keterangan palsu di atas sumpah. Pasal 242 KUHP, mengenai tindak pidana sumpah palsu atau keterangan palsu, ditentukan antara lain bahwa:

(1)Barang siapa dalam keadaan di mana undangundang mementukan supaya memberikan keterangan di atas sumpah atau mengadakan akibat hukum kepada keterangan yang demikian, dengan sengaja memberi keterangan palsu di atas sumpah, baik dengan lisan atau tulisan, secara pribadi maupun oleh kuasanya yang khusus ditunjuk untuk itu, diancam dengan pidana penjara paling lama tujuh tahun.

(2) Jika keterangan palsu di atas sumpah diberikan dalam perkara pidana dan merugikan terdakwa 
atau tersangka, yang bersalah diancam dengan pidana penjara paling lama sembilan tahun.

Adanya ancaman pidana terhadap perbuatan yang merupakan sumpah palsu dan keterangan palsu ini menjadi dasar yuridis bahwa saksi akan memberikan keterangan yang benar. Tetapi merupakan kenyataan bahwa adakalanya sebelum saksi memberikan keterangan di depan sidang pengadilan maka saksi yang bersangkutan telah "dilatih" terlebih dahulu oleh salah satu pihak, yaitu pihak terdakwa/penasihat hukum atau pihak korban. Ini dimaksudkan agar saksi tersebut memberikan keterangan sesuai dengan arah yang dikehendaki oleh penasihat hukum ataupun korban. Oleh karena itu, adakalanya Penasihat Hukum ataupun Jaksa Penuntut Umum di depan persidangan mengeluarkan pernyataan yang mengingatkan saksi bahwa ia memberikan keterangan masih di bawah sumpah. Terhadap pernyataan sedemikian adakalanya hakim memberikan reaksi yang bersifat negatif dengan mengeluarkan kata-kata seperti "saksi sudah tahu, tidak perlu diingatkan" atau "nanti hakim yang mengingatkan". Menurut penulis, karena sumpah merupakan satu-satunya jaminan hukum bahwa saksi akan memberikan keterangan yang sebenarnya, sedangkan manusia merupakan makhluk yang bersifat "pelupa", maka pernyataan yang bersifat mengingatkan saksi tersebut merupakan hal yang sebenarnya sewajarnya untuk dilakukan. Karenanya adalah lebih baik jika keinginan untuk mengingatkan saksi bahwa ia sedang memberikan keterangan masih di bawah sumpah, dijadikan suatu hak dari Penasihat Hukum dan Jaksa Penuntut Umum yang diatur secara tegas dalam KUHAP.

Keterangan notaris dan akta notaris tersebut dapat menjadi alat bukti yang sah apabila diperlukan dalam proses peradilan. Berdasarkan Putusan Mahkamah Agung Republik Indonesia nomor 685/ Pid.B/2016/PN Malang dan Putusan Mahkamah Agung Republik Indonesia nomor 603/Pid.B/2017/ PN Depansar sikap yang ditempuh notaris Roy Pudyo Hermawan, SH dan Ni Wayan Indah Setyawati, SH dengan cara ikut hadir dalam pemanggilan notaris untuk pemeriksaan peradilan pidana untuk memberikan keterangan sebagai saksi terkait akta perjanjian pengikatan jual beli yang dibuat oleh notaris tersebut. Keterangan yang diberikan oleh notaris tersebut menyangkut awal akta, isi akta, hingga akhir akta. Ini sama halnya membuka rahasia akta yang telah dibuatnya, disini hak ingkarnya sebagai notaris tidak dapat digunakan lagi karena telah memberikan keterangan terkait akta notaris tersebut, dan hal ini menggambarkan jelas melanggar sumpah jabatan notaris.

\section{Asas pemeriksaan hakim yang langsung dan lisan bagi saksi}

Pada asasnya dalam praktik pemeriksaan perkara pidana di depan persidangan dilakukan hakim secara langsung dan lisan, tidak menggunakan tulisan seperti dalam hukum acara perdata artinya langsung kepada terdakwa dan para saksi. Pemeriksaan hakim juga dilakukan secara lisan, artinya bukan tertulis antara hakim dan terdakwa (Hamzah, 1985:19).

Dapat disimpulkan bahwa asas pemeriksaan hakim yang langsung dan lisan bagi notaris apabila menjadi saksi dalam peradilan pidana harus hadir dalam persidangan sebgai saksi tidak di wakilkan oleh siapapun atau hanya akta notaris saja sebagai alat buktinya, akan tetapi keterangan dari notaris harus langsung dan lisan. Hal ini jelas menggambarkan bahwa hak ingkar notaris untuk melindungi aktanya dan mengemban sumpah jabatan sebagai notaris tidak bisa digunakan karena dalam hukum acara pidana yang dicari adalah kebenaran materiil.

Implikasi Hukum yang Timbul terhadap Hak Ingkar Notaris apabila Notaris telah Diizinkan oleh Majelis Kehormatan Notaris (MKN) untuk Hadir sebagai Saksi dalam Peradilan Pidana

Berkaitan dengan pemeriksaan notaris sebagai saksi dalam proses peradilan pidana sehubungan dengan penggunaan hak ingkar telah diatur pelaksanannya dalam Putusan Mahkamah Agung RI Nomor MA/Pemb/3425/86 tanggal 12 April 1986, khususnya dalam hurufg dan h. Huruf g, dalam kaitannya dengan sumpah jabatan notarisPPAT (Pasal 4 Ayat (2), Pasal 16 ayat (1) huruf e, dan pasal 54 Undang-undang jabatan notaris perubahan), Notaris-PPAT dapat meminta untuk dibebaskan dari kewajiban memberikan keterangan saksi sebagaimana diatur dalam Pasal 170 KUHAP atau dapat menolak memberikan keterangan sebagaimana diatur dalam Pasal 120 Ayat (2) KUHAP.

Huruf h, hak ingkar/tolak notaris-PPAT dapat dilepaskan demi kepentingan hukum atau 
kepentingan umum yang lebih tinggi nilainya dari kepentingan pribadi yang berkaitan dengan isi akta ataupun berdasrakan adanya peraturan umum yang memberikan pengecualian sebagaimana ditegaskan dalam Pasal 4 ayat (2), Pasal 16 ayat (1) huruf e, dan Pasal 54 UUJNP.

Berdasarkan paparan di atas, maka kewajiban untuk tidak bicara dapat dikesampingkan dalam hal terdapat kepentingan yang lebih tinggi yaitu dalam hal ini kepentingan umum. Mengingat hak ingkar adalah kewajiban notaris yang sifatnya melindungi rahasia para pihak yang sifatnya person atau orang tertentu saja. Ketentuan perundang- undangan mengkualifisir notaris sebagai wajib penyimpan rahasia karena jabatan, pekerjaan, harkat martabatnya. Hak ingkar dapat dikecualikan dengan Undang- undang yang telah disebutkan di atas. Oemar Seno Adji berpendapat verschoningsrecht (hak mengundurkan diri) tidak berlaku dalam hal yang menyangkut ketertiban dan keselamatan negara. Hal mana juga diungkapkan oleh Lumban Tobing, bahwa verschoningsrecht (hak mengundurkan diri) notaris dapat dikesampingkan dalam hal terdapat kepentingan- kepentingan yang lebih tinggi yang mengharuskan notrais untuk memberikan kesaksian (Tobing, 1992:127).

Selain itu, terdapat ketentuan dalam Pasal 50 KUHP yang menyatakan bahwa bagi mereka yang melakukan perbuatan untuk menjalankan peraturan perundang- undangan tidak boleh dipidana, maka dapat disimpulkan bahwa bagi notaris yang membuka rahasia jabatannya karena melakukan perintah Undang- undang. Dengan berlakunya ketentuan ini, maka notaris dapar dikenai sanksi apabila tidak hadir sebagai saksi. Namun mengenai hak ingkar tetap melekat pada notaris untuk menolak memberikan kesaksian khususnya mengenai kerahasian akta karena Undang- undang jabatan notaris secara tegas telah mengaturnya.

Implikasi hukum yang timbul terhadap hak ingkar notaris apabila notaris telah diizinkan oleh Majelis Kehormatan Notaris untuk hadir sebagai saksi dalam peradilan pidana yaitu bahwa hak ingkar notaris tersebut gugur, karena Undang- undang yang

\section{DAFTAR RUJUKAN}

Hamzah, Andi, 1985, Pengantar Hukum Acara Pidana Indonesia, Ghaila Indonesia, Jakarta.

Tobbing, G.H.S Lumban. 1992. Peraturan telah mengatur secara eksepsional atau pengecualian terhadap hak ingkar dikarenakan terdapat suatu kepentingan hukum yang lebih tinggi, maka dalam hal ini hak ingkar hanya dapat digunakan sepanjang tidak ada ketentuan peraturan perundang- undangan yang dapat menggugurkan hak ingkar notaris.

\section{SIMPULAN}

1. Hak ingkar notaris sebagai saksi dalam peradilan pidana tidak dapat digunakan karena 3 (tiga) faktor, yaitu: (a) system pembuktian pidana di Indonesia yang menjadikan akta autentik yang dibuat oleh dan dihadapan notaris menjadi salah satu alat bukti dari dua alat bukti yang minimal dibutuhkan hakim dalam memutus perkara. Hakim memerlukan mnimal 2 (dua) alat bukti dan keyakinan untuk memutus suatu perkara, sehingga tidak menutup kemungkinan bahwa keterangan notaris tersebut dapat menjadi salah satu alat bukti yang dibutuhkan hakim untuk memutus perkara pidana, (b) kedudukan keterangan saksi dalam pencarian kebenaran materiil, pemanggilan notaris untuk pemeriksaan peradilan pidana untuk memberikan keterangan sebagai saksi terkait akta perjanjian pengikatan yang dibuatnya, hal tersebut sama saja dengan membuka rahasia akta yang telah dibuatnya, (c) asas pemeriksaan hakim yang langsung dan lisan bagi saksi, pemeriksaan hakim yang langsung dan lisan terhadap notaris sebagai saksi dalam peradilan pidana, tidak dapat hanya akta notaris saja sebagai alat buktinya, tetapi keterangan dari notaris harus langsung dan lisan.

2. Implikasi hukum yang timbul terhadap hak ingkar notaris apabila notaris telah diizinkan oleh Majelis Kehormatan Notaris (MKN) untuk hadir sebagai saksi dalam peradilan pidana adalah gugurnya hak ingkar notaris karena adanya . kepentingan hukum yang lebih tinggi. Hak ingkar hanya dapat digunakan sepanjang tidak ada ketentuan peraturan perundang-undangan yang dapat menggugurkan hak ingkar notaris.

Jabatan Notaris, Erlangga, Jakarta. Sasangka, Hary dan Lily Rosita, 1996. Hukum

Pembuktian Dalam Perkara

Pidana. Sinar Wijaya. Surabaya. 